\title{
Chairman Characteristics and Earnings Management: Evidence from Chinese Listed Firms
}

\author{
Jiacai Xiong \\ School of Accountancy, Jiangxi University of Finance and Economics, Nanchang, China \\ Email: xiongjc-p@163.com
}

How to cite this paper: Xiong, J.C. (2016) Chairman Characteristics and Earnings Management: Evidence from Chinese Listed Firms. Open Journal of Accounting, 5, 8294.

http://dx.doi.org/10.4236/ojacct.2016.54008

Received: September 5, 2016

Accepted: October 7, 2016

Published: October 10, 2016

Copyright $\odot 2016$ by author and Scientific Research Publishing Inc. This work is licensed under the Creative Commons Attribution International License (CC BY 4.0).

http://creativecommons.org/licenses/by/4.0/

\begin{abstract}
Using a large sample of Chinese listed companies during period from 2005 to 2014, this paper investigates whether the managerial characteristics of Chairman affect earnings management. Using McNichols [1] accrual-based and Roychowdhury [2] real earning management, we find that companies with female, long-tenured, older and more educated Chairman have lower absolute discretionary accruals and lower real earnings management after controlling other factors that prior research has shown to be associated with earnings management. The results suggest that Chinese listed companies can improve earning quality by appointing more female, experienced, and educated chairmen, as well as increasing the tenure of Chairman.
\end{abstract}

\section{Keywords}

Earning Management, Gender, Tenure, Age, Education

\section{Introduction}

In this paper, we investigate whether the characteristics of Chairman of the board affect earnings management based on a large sample of Chinese listed companies.

Accounting information is of importance to firm's decision making, debt contract and corporate governance. Therefore, the accounting quality has attracted attention of investors, creditors and scholars. For China, although it has experienced incredible levels of growth, structural change and other factors that have enhanced its transformation, it is a critical issue for Chinese stock market regulators to increase earnings quality and thus enhance market efficiency [3].

Earning quality has received lots of attention. However, those researches keep keen concern on company characteristics, financial structure and external efforts in supervising and so on (Please refer to the review papers [2] [4]). It is often ignored that the characteristics of top managers have significant influences on financial strategy and re- 
source allocation.

Since Hambrick and Mason proposed upper echelons in 1984, top managers' characteristics have become the research object of academic. Under Chinese corporate law, the Chairman is the legal representative of the company; therefore, this person is endowed with the highest level of authority in the firm and bears the overall responsibility for firm operation. In most cases, the Chairman is also the highest paid employee. For these reasons, some studies regard the position of Chairman as the top management post in a firm [5].

Therefore, this study aims to provide empirical evidence and shed light on the relationship between characteristics of Chairman and earnings management by using a sample of Chinese firms that were publicly listed between 2005 and 2014. We find that companies with female, long-tenured, older and more educated Chairman have lower absolute discretionary accruals and lower real earnings management after controlling other factors that prior research has shown to be associated with earnings management.

The rest of the paper is organized as follows. Section 2 reviews the existing literature and develops testable hypotheses. Section 3 describes the research design, models, variable measures, and sample. Section 4 presents empirical evidence on whether Chairman's characteristics affect earnings management. Section 5 concludes the study.

\section{Literature Review and Hypothesis Development}

Hambrick and Mason [6] originally proposed upper echelons theory. It researches the company group of senior executives. The basic idea is the cognitive base and value, and these qualities will affect the manager's actions and decisions, thereby affecting the company's performance and organizational competitive behavior. Since the cognitive bases, values, and perception of upper level managers are inconvenient to measure, Hambrick and Mason [6] use observable managerial characteristics as indicators of impact and behaviors. In the paper, we choose gender, age, education and tenure that are the most represented factors to investigate whether those factors affect earnings management.

1) Gender

The female executives literature suggests that women tend to be less aggressive or more cautions in financial decision. For example, Riley and Chow [7] find that women are more risk averse than mean when making investment choices. Peng et al. [8] show that male managers are more apt to exhibit overconfidence in investment decisions when compared with female managers.

With regards to corporate governance, Adams and Ferreira [9] use a US firm's sample and find that female directors have better attendance records than male director. In addition, gender-diverse boards allocated more effector to monitoring and CEO turnover is more sensitive to stock performance in these firms.

In summary, prior research suggests that females are more caution and more likely to improve corporate governance. This lead to the argument that female Chairman are less likely to be aggressive in making judgments related to discretionary accruals and to 
have higher accruals quality.

Therefore, we formally state the hypothesis as follows:

H1: Ceteris paribus, firms with female Chairman will exhibit lower earnings management.

2) Tenure

Tenure of managers is another notable considerable factor in characteristic of senior management. Tenure affects cognitive foundation, prompt executives to make a different strategic choice, and eventually affect organizational performance. Tenure of senior managers has an effect on communication between the team and other executives. The longer the time to work jointly is, the better mutual understanding and communication between senior managers is. There will be fewer conflicts within the top management team. Organizational performance will be significantly improved [10]. If senior managers work in the company longer, they can more deeply understand the organization's policies and procedures. And organizational experience as an indicator variable, tenure also represents the level of familiarity with a common language in the internal organization [11]. The awareness of organization's resources and identification capability for external environment is positively correlated to tenure of managers.

Wiersema and Bantel [12] found that average tenure of bankrupt enterprises is shorter that the successful companies, which leads to lack of mutual understanding and information gathering time, finally giving rise to the mistakes of strategic decisionmaking. Thus, I hypothesize the following

H2: Ceteris paribus, firms with longer tenure Chairman will exhibit lower earnings management in China.

3) Age

Executives with different age show variety in the risk tendency and behaviors, which affects firm strategy and performance. An older Chairman tends to choose conservative strategy and becomes risk-averse tendency. Meanwhile, the older Chairman has lower passion and involvement to work, and is willing to live a peace condition. Therefore, decision-making tend to be steady [6] [13]. Prendergast and Stole1 [13] believe that in order to show their abilities, the young managers likely to exhibit over-confidence in corporate decision-making, meanwhile the greater possibility of manipulating earnings.

Moreover, the older Chairman has higher reputation compared with younger, so is not willing to exaggerate the earnings by earnings management. The older Chairman thinks risk things such as earnings management would affect their reputation. As well as, the older Chairman attaches more attention to risk management and promotes more stringent standards of control activity, then represses earnings management. He and Liu [14] show that the age of executives is negatively related to financial restatements.

Therefore, we propose the following hypothesis:

H3: Ceteris paribus, firms with older Chairman will exhibit lower earnings management.

4) Education 
To some extent, the individual's education level reflects their knowledge and skills. Thus, education can affect their values and decision-making of senior management by improving the cognitive education and skills.

It is believed that Chairman with relatively high education has a wider range of knowledge and more systematized knowledge system, and is thoughtful dealing with problems [6]. Furthermore, prior research finds that level of education is positively related to individual's cognitive complexity, receptivity to innovation and information processing capabilities [15].

Earnings management is comparatively more professional and higher risk activity. Chairman with higher level of education can efficiently acquire related accounting knowledge. As a result, he can analyze related information fully, see pattern of earnings management, understand the serious consequences of earnings management, and is keenly aware potential risk. He can prevent the behavior of earning management to occur. Therefore, we propose the hypothesis:

H4: Ceteris paribus, firms with higher education Chairman will exhibit lower earnings management.

\section{Research Design}

\subsection{Sample Selection}

This paper uses Chinese listed companies during 2005 and 2014 as analysis sample. Sample firms are listed on the boards of the Shenzhen and Shanghai stock exchanges. We exclude financial firms because their liabilities are not strictly comparable to those in other industries. The financial and accounting information data are extracted from the China Stock Market and Accounting Research (CSMAR) database commercially available from Shenzhen GTA Information Co. Ltd. To mitigate the influence of outliers, we winsorize each continuous variable at the first and 99th percentiles.

\subsection{Variable Definition}

The variables needed in the empirical analysis are variables reflected earnings management, variables reflected characteristics of Chairman and control variables. Related definition about variables as follow:

\subsubsection{Measuring Accrual-Based Earnings Management}

We use a cross-sectional model of accruals proposed by McNichols [1] to estimate discretionary accruals. She combines the Jones [16] and Dechow and Dichev [17] models, and uses the following model to estimate discretionary accruals.

$$
\frac{T A_{i t}}{A_{i t-1}}=\alpha_{0}+\alpha_{1} \frac{C F O_{i t-1}}{A_{i t-2}}+\alpha_{2} \frac{C F O_{i t}}{A_{i t-1}}+\alpha_{3} \frac{C F O_{i t+1}}{A_{i t}}+\alpha_{4} \frac{\Delta R E V_{i t}}{A_{i t-1}}+\alpha_{5} \frac{P P E_{i t}}{A_{i t-1}}+\varepsilon_{i t}
$$

where:

$T A_{i t}=$ total accruals for firm $i$ in year $t$, measured as the difference between income before extraordinary items and operating cash flows $\left(T A_{i t}=N I_{i t}-C F O_{i t}\right)$.

$A_{i t}=$ total assets for firm $i$ in year $t$. 
$C F O_{i t}=$ cash flow from operations for firm $i$ in year $t$.

$R E V_{i t}=$ change in revenues for firm $i$ from year $t-1$ to year $t$.

$P P E_{i t}=$ firm $i$ s gross property plant and equipment in year $t$.

$\boldsymbol{\varepsilon}_{i t}=$ error term.

We estimate Equation (1) separately for each one-digit industry-year group (manufacturing industry is based on two-digit), using all observation for which required data are available on CSMAR database. We also require that each group has at least ten observations. The residuals of these regressions are used as measures of discretionary accruals, which denoted as DA.

\subsubsection{Measuring Real Earnings Management}

Following Roychowdhury [2] and Cohen and Zarowin [18], we construct three measures of real earnings management. Concretely, we estimate abnormal production costs using the following Equations:

$$
\frac{P R O D_{i t}}{A_{i t-1}}=\alpha_{0}+\alpha_{1} \frac{1}{A_{i t-1}}+\alpha_{2} \frac{S A L E_{i t}}{A_{i t-1}}+\alpha_{3} \frac{\Delta S A L E_{i t}}{A_{i t-1}}+\alpha_{3} \frac{\Delta S A L E_{i t-1}}{A_{i t-1}}+\varepsilon_{i t}
$$

where $i$ and $t$ separately denotes firm and year, PROD is the sum of the cost of goods sold and the change in inventory from year $t-1$ to yeat $t . A$ is the firm's total assets. $S A L E$ is the firm's sales turnover.

We estimate abnormal discretionary expense from the following model:

$$
\frac{\text { EXPENSE }_{i t}}{A_{i t-1}}=\alpha_{0}+\alpha_{1} \frac{1}{A_{i t-1}}+\alpha_{2} \frac{S A L E_{i t-1}}{A_{i t-1}}+\varepsilon_{i t}
$$

where EXPENSE is the sum of selling expense and administrative expenses.

Finally, we estimate abnormal operating cash flow using the following model:

$$
\frac{C F O_{i t}}{A_{i t-1}}=\alpha_{0}+\alpha_{1} \frac{1}{A_{i t-1}}+\alpha_{2} \frac{S A L E_{i t}}{A_{i t-1}}+\alpha_{3} \frac{\Delta S A L E_{i t}}{A_{i t-1}}+\varepsilon_{i t}
$$

where $C F O$ is the operating cash flows.

Following Cohen and Zarowin [18], we combine the above three indicators to capture the overall effects of real earning management using the following Equations:

$$
R E M_{i t}=E M_{-} P R O D_{i t}-E M_{-} C F O_{i t}-E M_{-} E X P E N S E_{i t}
$$

$E M \_P R O D, E M \_C F O$ and EM_EXPENSE are the residuals of equations (2), (3) and (4). A higher value of REM suggests more real earnings management. We perform the regress for each industry-year group which has at least 10 observations.

\subsubsection{Chairman Characteristics}

According to Hypothesis development, in the paper, we define four explanatory variables, which are female Chairman (Female), Chairman's age (AGE), Chairman's tenure (Tenure), Chairman's education (EDU).

\subsubsection{Control Variables}

We analyze and test the relationship of explanatory variables and explained variables through multiple-regression. For avoiding the error of reject the null hypothesis and ensuring the validity and reliability of regression result, it is necessary to choose some 
control variables to control complicated factors.

Following Ye et al. [3] and Ali and Zhang [19], we controlled firm size, financial leverage, profitability, firm age, asset tangibility, Tobin's $Q$, institutional ownership and government control dummy. In addition, we also control industry and year fixed effects. See Table 1 for definition of variables.

\subsection{Regression Model}

We use the following regression model to test the hypothesis $\mathrm{H} 1$ to $\mathrm{H} 4$. The control variables in these models are based on prior literature (e.g., [3] [18] [19]).

$$
\begin{aligned}
& D A_{i t} / R E M_{i t}=\beta_{0}+\beta_{1} \text { Female }_{i t}+\beta_{2} A G E_{i t}+\beta_{3} E D U_{i t}+\beta_{4} \text { TENURE }_{i t} \\
& +\sum_{j} \text { Control varialbes }_{j, i t}+\sum \text { Industrydummies }+\sum \text { Yeardummies }+\mu_{i t}
\end{aligned}
$$

We estimate Equation (2) using ordinary lest squares (OLS). Following Peterson [20], we adjust the standard errors for heteroskedasticity and within-firm serial correlation using cluster at the firm level.

\begin{tabular}{|c|c|c|}
\hline Name & Variables & Definition \\
\hline Earnings management & DA & The ratio of discretionary accruals to total assets. \\
\hline $\begin{array}{l}\text { Real earning } \\
\text { management }\end{array}$ & REM & See Equation (2) to (5). \\
\hline Chairman's gender & Female & Female Chairman value 2, otherwise value 1 . \\
\hline Chairman's tenure & TENURE & $\begin{array}{l}\text { The year of the reporting period reduce the year of Chairman } \\
\text { inaugural the last time then plus } 1 .\end{array}$ \\
\hline Chairman's age & AGE & Chairman's age during the reporting period. \\
\hline Chairman's education & EDU & $\begin{array}{l}\text { Chairman whose education is equal or less than senior middle } \\
\text { school is equal } 1 \text {. Junior College Degree valued } 2 \text {. Bachelor's } \\
\text { degree valued 3.Master's degrees valued 4.A PhD valued } 5 \text {. }\end{array}$ \\
\hline The company size & SIZE & The natural logarithm of the total assets at the end of the year. \\
\hline Asset-liability ratio & LEV & $\begin{array}{l}\text { The total debt at the end of the year divided by total assets at } \\
\text { the end of the year. }\end{array}$ \\
\hline Return on equity & ROA & Net profit divided by shareholders' equity. \\
\hline Firm age & FirmAGE & The numbers of years the firm since the firm listed. \\
\hline Tangible & TANG & The ratio of tangible fixed assets to total assets. \\
\hline Tobin Q & Q & $\begin{array}{l}\text { Market capitalization at the end of year at the end of year } \\
\text { divided by the book value of total asset at the end of year. }\end{array}$ \\
\hline Institutional ownership & $\mathrm{IO}$ & $\begin{array}{l}\text { Institutional holdings (percent) form for I over year } \mathrm{t} \text { held by } \\
\text { all institutional investors. }\end{array}$ \\
\hline Government control & SOE & $\begin{array}{l}\text { SOE is equal to } 1 \text { if it is ultimately controlled by the } \\
\text { government. }\end{array}$ \\
\hline
\end{tabular}

Table 1. Definition of variables. 


\section{Empirical Results}

\subsection{Descriptive Statistics}

Table 2 provides descriptive statistics of the variables used in our study. The mean and median of DA (the ratio of discretionary accruals to total assets) are $8.1 \%$ and $5.8 \%$, respectively. In contrary, the mean (median) of real earnings management is $0.2 \%$ $(0.9 \%)$, which is smaller compared with accrual-based earnings management.

With regards to Chairman characteristics, we find that women occupy about $4.3 \%$ of the chair of the board, which is similar to Ye et al. [3]. The mean and median Chairman tenure is 4.562 and 4 year, which is lower compared to US firm [19]. The mean age and education is 50.62 and 3.45

Table 3 presents the correlation matrix of the variables. This table illustrates that discretionary accruals exhibit weak correlation with real earnings management, indicating that these measures capture different aspects of earnings management activities. As regards the gender of the chair of the board, Table 3 shows that female Chairman

Table 2. Descriptive statistics.

\begin{tabular}{ccccccc}
\hline Variable & $\mathrm{N}$ & Mean & Standard Deviation & Median & Minimum & Maximum \\
\hline DA & 19,175 & 0.081 & 0.079 & 0.058 & 0.001 & 0.431 \\
REM & 17,644 & 0.002 & 0.167 & 0.009 & -0.353 & 0.310 \\
Female & 18,832 & 0.043 & 0.203 & 0 & 0 & 1 \\
Tenure & 18,337 & 4.562 & 2.988 & 4 & 1 & 14 \\
AGE & 18,803 & 50.62 & 7.111 & 50 & 34 & 68 \\
EDU & 8,039 & 3.450 & 0.895 & 4 & 1 & 5 \\
SIZE & 19,175 & 21.55 & 1.189 & 21.41 & 18.77 & 25.20 \\
LEV & 19,175 & 0.493 & 0.238 & 0.492 & 0.049 & 1.603 \\
ROA & 19,175 & 0.032 & 0.071 & 0.034 & -0.311 & 0.238 \\
FirmAGE & 19,175 & 8.046 & 5.031 & 8 & -1 & 21 \\
TANG & 19,175 & 0.273 & 0.181 & 0.242 & 0.001 & 0.757 \\
Q & 19,175 & 1.911 & 1.709 & 1.405 & 0.244 & 10.35 \\
IO & 19,175 & 0.151 & 0.187 & 0.072 & 0 & 0.751 \\
SOE & 19,175 & 0.596 & 0.491 & 1 & 0 & 1 \\
\hline
\end{tabular}

Note: The sample period is from 2005 to 2014 and extracted from the China Stock Market and Accounting Research (CSMAR) database. $D A_{i t}$ is discretionary accruals of firm $i$ in year $t$, estimated as the residual of accruals model (Equation (1)). $R E M_{i t}$ is real earning management of firm $i$ and year $t$, estimate using Equations (2) to (5). Female $_{i t}$ is a dummy variable, assigning value one in case where the Chairman is female, and zero male. Tenure $_{i t}$ is the Chairman tenure. $A G E_{i t}$ and $E d u_{i t}$ are Chairman's age and education. $S I Z E_{i t}$ is the natural logarithm of the total assets. $L E V_{i t}$ is defined as total debt divided by total asset at the end of year $t$. Firm $A G E_{i t}$ is the number of years since a firm's IPO. $T A N G_{i t}$ is defined as the ratio of tangible fixed assets to total assets. $Q_{i t}$ is Tobin'Q, equaling market value of assets scaled by book value of assets. $I O_{i t}$ is the percentage of stocks held by institutional investor at the end of year $t . S O E_{i t}$ is government control dummy variable, coded 1 for firm-year that that have a government institution as the controlling shareholder and 0 otherwise. 
Table 3. Correlation matrix.

\begin{tabular}{|c|c|c|c|c|c|c|c|c|c|c|c|c|c|c|}
\hline & DA & REM & Female & Tenure & AGE & EDU & SIZE & LEV & $\mathrm{ROA}$ & FirmAGE & TANG & $\mathrm{Q}$ & IO & SOE \\
\hline DA & 1 & & & & & & & & & & & & & \\
\hline Female & 0.002 & $-0.015^{\star *}$ & 1 & & & & & & & & & & & \\
\hline Tenure & $-0.083^{\star * *}$ & $-0.047^{\star \star *}$ & 0.010 & 1 & & & & & & & & & & \\
\hline EDU & $-0.026^{\star *}$ & 0.007 & $-0.022^{\star *}$ & $0.020^{* *}$ & $-0.229^{* * *}$ & 1 & & & & & & & & \\
\hline SIZE & $-0.121^{\star * *}$ & $-0.029^{\star * *}$ & $-0.024^{\star * \star}$ & $0.200^{\star * *}$ & $0.215^{\star * *}$ & $0.161^{\star * *}$ & 1 & & & & & & & \\
\hline LEV & $0.185^{\star * *}$ & $0.109^{* * *}$ & -0.003 & -0.006 & $-0.057^{\star * *}$ & $0.088^{* * *}$ & $0.168^{* * *}$ & 1 & & & & & & \\
\hline Q & $0.125^{\star \star \star}$ & $-0.135^{\star * *}$ & 0.009 & $-0.087^{\star * *}$ & $-0.084^{\star \star \star}$ & -0.001 & $-0.451^{\star * *}$ & $-0.262^{\star * *}$ & $0.188^{\star * \star}$ & $-0.118^{\star * *}$ & $-0.131^{\star \star \star}$ & 1 & & \\
\hline IO & $-0.020^{* * *}$ & $-0.130^{\star * *}$ & -0.007 & $0.090^{* * *}$ & $0.049^{* * *}$ & $0.046^{* * *}$ & $0.139^{* * *}$ & $-0.063^{\star * *}$ & $0.172^{\star * *}$ & $0.201^{\star * *}$ & -0.010 & $0.082^{* * *}$ & 1 & \\
\hline SOE & $-0.069^{\star * \star}$ & $0.016^{\star *}$ & $-0.037^{\star * *}$ & $-0.084^{* * *}$ & $0.065^{\star * *}$ & $0.186^{* * *}$ & $0.284^{\star * *}$ & $0.146^{* * *}$ & $-0.097^{* * *}$ & $0.515^{\star * *}$ & $0.228^{* * *}$ & $-0.174^{* * *}$ & $0.179^{* * *}$ & 1 \\
\hline
\end{tabular}

Note: The sample period is from 2005 to 2014 and extracted from the China Stock Market and Accounting Research (CSMAR) database. ${ }^{* * *},{ }^{* *}$ and ${ }^{*}$ denote significance at $1 \%, 5 \%$, and $10 \%$ level, respectively. $D A_{i t}$ is discretionary accruals of firm $i$ in year $t$, estimated as the residual of accruals model (Equation (1)). $R E M_{i t}$ is real earning management of firm $i$ and year $t$, estimate using Equations (2) to (5). Female $e_{i t}$ is a dummy variable, assigning value one in case where the Chairman is female, and zero male. Tenure it is the Chairman tenure. $A G E_{i t}$ and $E D U_{i t}$ are Chairman's age and education. $S I Z E_{i t}$ is the natural logarithm of the total assets. $L E V_{i t}$ is defined as total debt divided by total asset at the end of year $t$. Firm $A G E_{i t}$ is the number of years since a firm's IPO. $T A N G_{i t}$ is defined as the ratio of tangible fixed assets to total assets. $Q_{i t}$ is Tobin'Q, equaling market value of assets scaled by book value of assets. $I O_{i t}$ is the percentage of stocks held by institutional investor at the end of year t. $S O E_{i t}$ is government control dummy variable, coded 1 for firm-year that that have a government institution as the controlling shareholder and 0 otherwise.

shows a lower tendency to do real earnings management, and demonstrate no significant correlation with discretionary accruals. In addition, the longer tenure, older and higher educated Chairman has a lower probability to engage in either discretionary or real earning management.

\subsection{Regression Results}

\subsubsection{Chairman Characteristic and Discretionary Accruals}

Table 4 reports panel regression estimates of Equation (6) using discretionary accruals as dependent variables. The standard errors of these regressions as well as other regression in this paper are clustered by firm. In the columns (1) to (4), we regress discretionary accruals on female Chairman (Female), Chairman tenure (TENURE), Chairman age $(A G E)$ and Chairman education (EDU) respectively. In column (5), we put all the characteristics variables into model together.

As shown in Table 4, the female Chairman variable is not significant in column (1). However, when we include all the variables, the coefficient estimates for Female is significantly negative at the $10 \%$ level, suggesting that female Chairman exhibits lower discretionary accruals management. This is consistent with idea that female helps to improve corporate governance [9]. 
Table 4. Regressions of discretionary accrual on Chairman characteristic.

\begin{tabular}{|c|c|c|c|c|c|}
\hline & (1) & (2) & (3) & (4) & (5) \\
\hline \multirow[t]{2}{*}{ SIZE } & $-0.003^{* * *}$ & $-0.003^{* * *}$ & $-0.003^{* * *}$ & $-0.003^{* * *}$ & $-0.002^{\star *}$ \\
\hline & $(0.001)$ & $(0.001)$ & $(0.001)$ & $(0.001)$ & $(0.001)$ \\
\hline \multirow[t]{2}{*}{ LEV } & $0.071^{\star * \star}$ & $0.070^{\star * *}$ & $0.070^{\star * *}$ & $0.064^{\star * *}$ & $0.061^{\star * *}$ \\
\hline & $(0.005)$ & $(0.005)$ & $(0.005)$ & $(0.007)$ & $(0.007)$ \\
\hline \multirow[t]{2}{*}{ ROA } & -0.010 & -0.006 & -0.010 & -0.004 & 0.001 \\
\hline & $(0.017)$ & $(0.017)$ & $(0.017)$ & $(0.025)$ & $(0.024)$ \\
\hline \multirow[t]{2}{*}{ FirmAGE } & 0 & 0 & 0 & 0 & 0 \\
\hline & $(0.000)$ & $(0.000)$ & $(0.000)$ & $(0.000)$ & $(0.000)$ \\
\hline \multirow[t]{2}{*}{ TANG } & $-0.021^{* * *}$ & $-0.020^{\star * *}$ & $-0.020^{* * *}$ & $-0.029^{* * *}$ & $-0.025^{* * *}$ \\
\hline & $(0.005)$ & $(0.005)$ & $(0.005)$ & $(0.008)$ & $(0.007)$ \\
\hline \multirow[t]{2}{*}{ Q } & $0.006^{* * *}$ & $0.006^{* * *}$ & $0.006^{* * *}$ & $0.005^{\star * *}$ & $0.005^{* * *}$ \\
\hline & $(0.001)$ & $(0.001)$ & $(0.001)$ & $(0.001)$ & $(0.001)$ \\
\hline \multirow[t]{2}{*}{ IO } & 0.002 & 0.002 & 0.002 & 0.005 & 0.005 \\
\hline & $(0.004)$ & $(0.004)$ & $(0.004)$ & $(0.005)$ & $(0.005)$ \\
\hline \multirow[t]{2}{*}{ SOE } & $-0.009^{* * *}$ & $-0.010^{* * *}$ & $-0.009^{* * *}$ & $-0.010^{* * *}$ & $-0.010^{* * *}$ \\
\hline & $(0.002)$ & $(0.002)$ & $(0.002)$ & $(0.003)$ & $(0.002)$ \\
\hline \multirow[t]{2}{*}{ Female } & -0.002 & & & & $-0.008^{*}$ \\
\hline & $(0.003)$ & & & & $(0.004)$ \\
\hline \multirow[t]{2}{*}{ TENURE } & & $-0.001^{\star * *}$ & & & $-0.001^{* * *}$ \\
\hline & & $(0.000)$ & & & $(0.000)$ \\
\hline \multirow[t]{2}{*}{ AGE } & & & $-0.000^{* * *}$ & & $-0.000^{* *}$ \\
\hline & & & $(0.000)$ & & $(0.000)$ \\
\hline \multirow[t]{2}{*}{ EDU } & & & & $-0.003^{\star *}$ & $-0.004^{* * *}$ \\
\hline & & & & $(0.001)$ & $(0.001)$ \\
\hline \multirow[t]{2}{*}{ Constant } & $0.111^{\star * *}$ & $0.107^{* * *}$ & $0.120^{* * *}$ & $0.127^{* * *}$ & $0.130^{* * *}$ \\
\hline & $(0.018)$ & $(0.018)$ & $(0.018)$ & $(0.027)$ & $(0.026)$ \\
\hline $\mathrm{N}$ & 14543 & 14334 & 14522 & 6746 & 6615 \\
\hline $\mathrm{R}^{2}$ & 0.0720 & 0.0760 & 0.0730 & 0.0570 & 0.0600 \\
\hline Adj- $R^{2}$ & 0.0700 & 0.0730 & 0.0710 & 0.0520 & 0.0550 \\
\hline $\mathrm{F}$ & 15.62 & 16.52 & 15.58 & 6.533 & 6.986 \\
\hline
\end{tabular}

Note: The sample period is from 2005 to 2014 and extracted from the China Stock Market and Accounting Research (CSMAR) database. The model is estimated with pooled panel data, using robust standard errors and clustering by firms. ${ }^{* *},{ }^{* *}$ and ${ }^{*}$ denote significance at $1 \%, 5 \%$, and $10 \%$ level, respectively. $D A_{i t}$ is discretionary accruals of firm $i$ in year $t$, estimated as the residual of accruals model (Equation (1)). Female $e_{i t}$ is a dummy variable, assigning value one in case where the Chairman is female, and zero male. Tenure $e_{i t}$ is the Chairman tenure. $A G E_{i t}$ and $E D U_{i t}$ are Chairman's age and education. $S I Z E_{i t}$ is the natural logarithm of the total assets. $L E V_{i t}$ is defined as total debt divided by total asset at the end of year $t$. Firm $A G E_{i t}$ is the number of years since a firm's IPO. $T A N G_{i t}$ is defined as the ratio of tangible fixed assets to total assets. $Q_{i t}$ is Tobin'Q, equaling market value of assets scaled by book value of assets. $I O_{i t}$ is the percentage of stocks held by institutional investor at the end of year t. $S O E_{i t}$ is government control dummy variable, coded 1 for firm-year that that have a government institution as the controlling shareholder and 0 otherwise. 
Table 5. Regressions of real earning management on Chairman characteristics.

\begin{tabular}{|c|c|c|c|c|c|}
\hline & (1) & (2) & (3) & (4) & (5) \\
\hline \multirow[t]{2}{*}{ SIZE } & $-0.010^{* * *}$ & $-0.009^{* * *}$ & $-0.009^{* * *}$ & $-0.007^{* *}$ & $-0.006^{* * *}$ \\
\hline & $(0.003)$ & $(0.003)$ & $(0.003)$ & $(0.003)$ & $(0.002)$ \\
\hline \multirow[t]{2}{*}{ LEV } & 0.009 & 0.007 & 0.006 & -0.007 & -0.009 \\
\hline & $(0.011)$ & $(0.011)$ & $(0.011)$ & $(0.017)$ & $(0.012)$ \\
\hline \multirow[t]{2}{*}{$\mathrm{ROA}$} & $-0.753^{\star \star \star}$ & $-0.747^{\star * *}$ & $-0.749^{* * *}$ & $-0.959^{\star \star \star}$ & $-0.954^{\star * *}$ \\
\hline & $(0.042)$ & $(0.042)$ & $(0.042)$ & $(0.059)$ & $(0.044)$ \\
\hline \multirow[t]{2}{*}{ FirmAGE } & 0 & 0 & 0 & -0.00100 & $-0.001^{*}$ \\
\hline & $(0.000)$ & $(0.000)$ & $(0.000)$ & $(0.001)$ & $(0.000)$ \\
\hline \multirow[t]{2}{*}{ TANG } & $-0.148^{\star * \star}$ & $-0.144^{\star * *}$ & $-0.145^{\star * *}$ & $-0.134^{\star * \star}$ & $-0.128^{\star * \star}$ \\
\hline & $(0.014)$ & $(0.014)$ & $(0.014)$ & $(0.021)$ & $(0.013)$ \\
\hline \multirow[t]{2}{*}{ Q } & $-0.016^{\star * *}$ & $-0.016^{* * *}$ & $-0.016^{* * *}$ & $-0.015^{\star * *}$ & $-0.015^{\star * *}$ \\
\hline & $(0.002)$ & $(0.002)$ & $(0.002)$ & $(0.002)$ & $(0.002)$ \\
\hline \multirow[t]{2}{*}{ IO } & $-0.072^{\star * *}$ & $-0.071^{* * *}$ & $-0.072^{* * *}$ & $-0.049^{* * *}$ & $-0.050^{* * *}$ \\
\hline & $(0.011)$ & $(0.011)$ & $(0.011)$ & $(0.015)$ & $(0.010)$ \\
\hline \multirow[t]{2}{*}{ SOE } & 0.007 & 0.006 & 0.008 & 0.003 & 0.004 \\
\hline & $(0.006)$ & $(0.006)$ & $(0.006)$ & $(0.008)$ & $(0.005)$ \\
\hline \multirow[t]{2}{*}{ Female } & -0.011 & & & & $-0.020^{\star *}$ \\
\hline & $(0.011)$ & & & & $(0.009)$ \\
\hline \multirow[t]{2}{*}{ TENURE } & & $-0.002^{* * *}$ & & & -0.001 \\
\hline & & $(0.001)$ & & & $(0.001)$ \\
\hline \multirow[t]{2}{*}{ AGE } & & & $-0.001^{\star * *}$ & & $-0.001^{* * *}$ \\
\hline & & & $(0.000)$ & & $(0.000)$ \\
\hline \multirow[t]{2}{*}{ EDU } & & & & -0.004 & $-0.006^{\star * *}$ \\
\hline & & & & $(0.003)$ & $(0.002)$ \\
\hline \multirow[t]{2}{*}{ Constant } & $0.338^{\star * *}$ & $0.329^{* * *}$ & $0.361^{\star * \star}$ & $0.307^{* * *}$ & $0.337^{* * *}$ \\
\hline & $(0.058)$ & $(0.056)$ & $(0.057)$ & $(0.071)$ & $(0.050)$ \\
\hline $\mathrm{N}$ & 16118 & 15887 & 16101 & 7325 & 7178 \\
\hline $\mathrm{R}^{2}$ & 0.145 & 0.145 & 0.147 & 0.187 & 0.187 \\
\hline $\operatorname{Adj}-R^{2}$ & 0.143 & 0.143 & 0.145 & 0.183 & 0.183 \\
\hline F & 23.47 & 23.00 & 23.83 & 16.79 & 31.39 \\
\hline
\end{tabular}

Note: The sample period is from 2005 to 2014 and extracted from the China Stock Market and Accounting Research (CSMAR) database. The model is estimated with pooled panel data, using robust standard errors and clustering by firms. ${ }^{* *},{ }^{* *}$ and ${ }^{*}$ denote significance at $1 \%, 5 \%$, and $10 \%$ level, respectively. $R E M_{i t}$ is real earning management of firm $i$ and year $t$, estimate using Equations (2) to (5). Female $e_{i t}$ is a dummy variable, assigning value one in case where the Chairman is female, and zero male. Tenure $_{i t}$ is the Chairman tenure. $A G E_{i t}$ and $E D U_{i t}$ are Chairman's age and education. $S I Z E_{i t}$ is the natural logarithm of the total assets. $L E V_{i t}$ is defined as total debt divided by total asset at the end of year $t$. Firm $A G E_{i t}$ is the number of years since a firm's IPO. $T A N G_{i t}$ is defined as the ratio of tangible fixed assets to total assets. $Q_{i t}$ is Tobin'Q, equaling market value of assets scaled by book value of assets. $I O_{i t}$ is the percentage of stocks held by institutional investor at the end of year $t$. SOE $E_{i t}$ is government control dummy variable, coded 1 for firm-year that that have a government institution as the controlling shareholder and 0 otherwise. 
The column (2) and (5) of Table 4 show that the coefficient for TENURE is -0.001 and significant at the $1 \%$ level, suggesting that Chairman with long tenured report less aggressively, which supports our hypothesis 2 .

In column (3), (4) and (5), the coefficient on $A G E$ and $E D U$ are both negative and significant, indicating that Chairman with more education and older are less likely to overstating earnings, which is consistence with hypothesis 3 and 4.

\subsubsection{Chairman Characteristics and Real Earnings Management}

Table 5 reports panel regression results of the real earnings management. In the columns (1) to (4), we regress discretionary accruals on female Chairman (Female), Chairman tenure (TENURE), Chairman age $(A G E)$ and Chairman education (EDU) respectively. In column (5), we put all the characteristics variables into model together.

In column (5), the coefficient on Female is negative and significant, -0.02 (t-statistics $=-2.09$ ), suggesting that female Chairman are less likely to engage real earnings management.

In column (2) of Table 5, the coefficient on TENURE is significant negative, consistent with the notion that Chairman with long tenured are less likely to inflate performance through real activities management.

The last three column of Table 5 show that older and more educated Chairman are engage in less real earnings management.

Combining results of Table 4 and Table 5, we find that the firms with female, long-tenured, older and more educated Chairman report lower earning management, either accrual-based or real-based.

\section{Conclusion}

Anecdotal evidence [6] suggests that observable managerial characteristics will affect the manager's actions and decisions, which in turn affect the company's performance and organizational competitive behavior. This study extends the literature that examines whether top executive characteristics affect earnings management in the context of an emerging market, China. Using a large sample of Chinese listed companies during period from 2005 to 2014, we find that firms with female, long-tenured, older and more education chairman engage in less accrual-based and real earnings management. Our results indicate that Chinese listed companies can enhance earnings by hiring more female, education and older chairmen, and by signing a long-term contract with chairman.

\section{Acknowledgements}

I acknowledge financial support from the National Natural Science Foundation of China (Grant No. 71562015), Postdoctoral Science Foundation of China (Grant No. 2015M571985), Postdoctoral Science Foundation of Jiangxi Province (Grant No. 2015KY25), Social Science Foundation of Jiangxi Province (Grant No. 15GL29), Social Science University Humanity of Jiangxi Province (Grant No. GL1522). 


\section{References}

[1] McNichols, M.F. (2002) Discussion of the Quality of Accruals and Earnings: The Role of Accrual Estimation Errors. Accounting Review, 77, 61-69. http://dx.doi.org/10.2308/accr.2002.77.s-1.61

[2] Roychowdhury, S. (2006) Earnings Management through real Activities Manipulation. Journal of Accounting and Economics, 42, 335-370. http://dx.doi.org/10.1016/j.jacceco.2006.01.002

[3] Ye, K.T., Zhang, R. and Rezaee, Z. (2010) Does Top Executive Gender Diversity Affect Earnings Quality? A Large Sample Analysis of Chinese Listed Firms. Advances in Accounting, 26, 47-54. http://dx.doi.org/10.1016/j.adiac.2010.02.008

[4] Dechow, P.M., Ge, W.L. and Schrand, C. (2010) Understanding Earnings Quality: A Review of the Proxies, Their Determinants and Their Consequences. Journal of Accounting and Economics, 50, 344-401. http://dx.doi.org/10.1016/j.jacceco.2010.09.001

[5] Firth, M., Fung, P.M.Y. and Rui, O.M. (2006) Firm Performance, Governance Structure, and Top Management Turnover in a Transitional Economy. Journal of Management Studies, 43, 1289-1330. http://dx.doi.org/10.1111/j.1467-6486.2006.00621.x

[6] Hambrick, D.C. and Mason, P.A. (1984) Upper Echelons: Organization as a Reflection of Its Managers. Academy Management Review, 9, 193-206.

[7] Riley, W.B. and Chow, K.V. (1992) Asset Allocation and Individual Risk Aversion. Financial Analysts Journal, 48, 32-37. http://dx.doi.org/10.2469/faj.v48.n6.32

[8] Peng, W.Q. and Wei, K.C.J. (2007) Women Executives and Corporate Investment: Evidence from the S\&P 1500.Working Paper, Hong Kong University of Science and Technology, Hong Kong.

[9] Adams, R. and Ferreira, D. (2009) Women in the Boardroom and Their Impact on Governance and Performance. Journal of Financial Economics, 94, 291-309.

http://dx.doi.org/10.1016/j.jfineco.2008.10.007

[10] Katz, R. (1982) The Effects of Group Longevity on Project Communication and Performance. Administrative Science Quarterly, 27, 548-570. http://dx.doi.org/10.2307/2392547

[11] Zenger, T. and Lawrence, B. (1989) Organizational Demography: The Differential Effects of Age and Tenure on Communication. Academy of Management Journal, 32, 353-376. http://dx.doi.org/10.2307/256366

[12] Wiersema, M.F. and Bantel, K.A. (1992) Top Management Team Demography and Corporate Strategic Change. Academy of Management Journal, 35, 91-121.

http://dx.doi.org/10.2307/256474

[13] Prendergast, C. and Stole1, L. (1996) Impetuous Youngsters and Jaded Old-Timers: Acquiring a Reputation for Learning. Journal of Political Economy, 104, 1105-1134. http://dx.doi.org/10.1086/262055

[14] He, W.F. and Liu, Q.L. (2010) A Study on the Relationship between the Characteristics of the Background of the Top Managers of China's Listed Companies and Their Behavior of Financial Restatement. Management World, No. 7, 144-155. (In Chinese)

[15] Kimberly, J. and Evanisko, M. (1981) Organizational Innovation: The Influence of Individual, Organizational, and Contextual Factors on Hospital Adoption of Technological and Administrative Innovations. Academy of Management Journal, 24, 689-713. http://dx.doi.org/10.2307/256170

[16] Jones, J. (1991) Earnings Management during Import Relief Investigations. Journal of Accounting Research, 29, 193-228. http://dx.doi.org/10.2307/2491047 
[17] Dechow, P.M. and Dichev, I. (2002) The Quality of Accruals and Earnings: The Role of Accrual Estimation Errors. Accounting Review, 77, 35-59.

http://dx.doi.org/10.2308/accr.2002.77.s-1.35

[18] Cohen, D.A. and Zarowin, P. (2010) Accrual-Based and Real Earnings Management Activities around Seasoned Equity Offerings. Journal of Accounting and Economics, 50, 2-19. http://dx.doi.org/10.1016/j.jacceco.2010.01.002

[19] Ali, A. and Zhang, W.N. (2015) CEO Tenure and Earnings Management. Journal of Accounting and Economics, 59, 60-79. http://dx.doi.org/10.1016/j.jacceco.2014.11.004

[20] Petersen, M. (2009) Estimating Standard Errors in Finance Panel Data Sets: Comparing Approaches. Review of Financial Studies, 22, 435-480. http://dx.doi.org/10.1093/rfs/hhn053

\section{Submit or recommend next manuscript to SCIRP and we will provide best service} for you:

Accepting pre-submission inquiries through Email, Facebook, LinkedIn, Twitter, etc. A wide selection of journals (inclusive of 9 subjects, more than 200 journals)

Providing 24-hour high-quality service

User-friendly online submission system

Fair and swift peer-review system

Efficient typesetting and proofreading procedure

Display of the result of downloads and visits, as well as the number of cited articles

Maximum dissemination of your research work

Submit your manuscript at: http://papersubmission.scirp.org/

Or contact ojacct@scirp.org 